Keiko Nagata $\cdot$ Toshiyuki Yamamoto $\cdot$ Hiroki Chikumi

Toshikazu Ikeda $\cdot$ Hiroyuki Yamamoto

Kiyoshi Hashimoto • Kazuhiko Yoneda • Eiji Nanba

Haruaki Ninomiya · Kazuyuki Ishitobi

\title{
A novel interstitial deletion of KAL1 in a Japanese family with Kallmann syndrome
}

Received: March 17, 2000 / Accepted: May 9, 2000

\begin{abstract}
We identified a novel interstitial deletion that spanned from exons 5 to 10 of $K A L 1$ in two Japanese brothers with X-linked Kallmann syndrome (KS; MIM no. 308700). Both brothers had hypogonadism, unilateral renal agenesis, and disturbance of the sense of smell, but they had no other neurological manifestations, including mental disturbance. Their mother was confirmed to be an asymptomatic carrier, by use of a comparative multiplex polymerase chain reaction (PCR) analysis. The present patients are further examples of patients with $\mathrm{KS}$ without mental disturbance caused by a mutation confined to KAL1.
\end{abstract}

Key words Kallmann syndrome • KAL1 - Mutation · Anosmia $\cdot$ Hypogonadism

\section{Introduction}

Kallmann syndrome (KS; MIM no. 308700) is characterized by hypogonadotropic hypogonadism and disturbance in the sense of smell (hyposmia/anosmia); KS is also often associated with various other symptoms, including mental disturbance. A segregation analysis revealed genetic het-

K. Nagata $(\varangle) \cdot$ H. Chikumi $\cdot$ T. Ikeda $\cdot$ H. Yamamoto ·

$\mathrm{K}$. Hashimoto $\cdot \mathrm{K}$. Yoneda

The Third Department of Internal Medicine, Faculty of Medicine,

Tottori University, 36-1 Nishi-machi, Yonago 683-8504, Japan

Tel. +81-859-34-8105; Fax +81-859-34-8098

e-Mail: nanamon@grape.med.tottori-u.ac.jp

T. Yamamoto $\cdot$ E. Nanba

Gene Research Center, Tottori University, Yonago, Japan

H. Ninomiya

Department of Neurobiology, School of Life Sciences, Faculty of Medicine, Tottori University, Yonago, Japan

K. Ishitobi

Health Science Center, Tottori University, Tottori, Japan erogeneity, with $\mathrm{X}$-linked, autosomal recessive, and autosomal dominant modes of transmission (Georgopoulos et al. 1997). The KAL1 gene (KAL1: Genbank accession number, M97252), responsible for the X-linked form of KS, was identified on Xp22.3. Here, we describe a Japanese family with $\mathrm{KS}$ associated with a novel interstitial deletion in $K A L 1$.

\section{Subjects and methods}

Genomic DNAs were prepared from the peripheral blood of the family members and Japanese volunteers by a phenol/ chloroform method. Each of the 14 exons of KAL1 was amplified using polymerase chain reaction (PCR) primers designed according to Hardelin et al. (1992).

The quantity of KAL1 PCR products was evaluated using NPC1 PCR products as an internal standard. NPC1 (Genbank accession number, AF002020) is a gene responsible for Niemann-Pick disease type C (MIM, 257220) and is located on $18 \mathrm{q}$. The PCR contained $40 \mathrm{pmol}$ of each primer (exon 7 of KAL1 and exon 20 of NPC1: 5'-GTA ATG CCC CTC ACT GTC AG-3' and 5'-GTC TTA GCC CAG TCC TCT CC-3'), $2.5 \mathrm{nM}$ of dNTPs (Gene Amp dNTPs mix), 100ng of genomic DNA, standard PCR buffer, and $1 \mathrm{U}$ of Ampli Taq Gold (Perkin Elmer, Norwalk, CT, USA) in a final volume of $10 \mu \mathrm{l}$. Cycling conditions were $10 \mathrm{~min}$ at $95^{\circ} \mathrm{C}$ initial denaturation, $20-35$ cycles of $30 \mathrm{~s}$ at $95^{\circ} \mathrm{C}, 30 \mathrm{~s}$ at $55^{\circ} \mathrm{C}$, and $60 \mathrm{~s}$ at $72^{\circ} \mathrm{C}$, followed by a final extension for $5 \mathrm{~min}$ at $72^{\circ} \mathrm{C}$. The amplified products were analyzed by electrophoresis on a $6 \%$ polyacrylamide gel and with SYBR Green staining (Molecular Probe, Eugene, OR, USA). The intensity of each band was measured using a densitometer (Atto, Tokyo, Japan) and the intensities of $K A L 1$ bands were evaluated as relative to the intensities of NPC1 bands (KAL1/NPC1 ratio). To verify that the obtained ratio reflected the gene dosage in the templates, samples from 10 male and 11 female subjects were also examined. 


\section{Results and discussion}

The probands were the two male offspring (patient 1, aged 33 years, and patient 2 , aged 29 years) of three offspring (the other was a healthy female) of healthy parents. Both brothers had been operated on for cryptorchism and had received gonadotropin replacement therapy since their early teens. Patient 1 had a standard stature with a height of $174 \mathrm{~cm}(+0.643 \mathrm{SD})$ and weighted $62 \mathrm{~kg}$ (body mass index [BMI], 20.5); patient $2 \mathrm{had}$ a height of $177 \mathrm{~cm}(+1.88 \mathrm{SD})$, weighed $104 \mathrm{~kg}$ (BMI, 33.2), and was obviously obese (Fig. 1). Both patients had a mild eunuchoid appearance and both had unilateral renal aplasia, as revealed by ultrasonography. Both had normal intelligence and neither had any neurological signs. Although neither of the patients had subjective complaints of hyposmia, both were revealed to have a cryptic disturbance of the olfactory sense, by the use of an alinamin infusion test and the T\&T olfactometer test. Both of them had low levels of serum testosterone and luteinizing hormone, follicle stimulating hormone $(\mathrm{LH}$, FSH), which did not respond to human chorionic gonadotropin (hCG) and gonadotropin releasing hormone $(\mathrm{GnRH})$ stimulation, respectively.

All of the $K A L 1$ exons were successfully amplified from control genomic DNAs, whereas six exons (exons 5-10) were not amplified from the DNAs of the probands (Fig. 2a), suggesting the presence of an interstitial deletion that spanned from exon 5 to exon 10 in both patients' DNAs. To

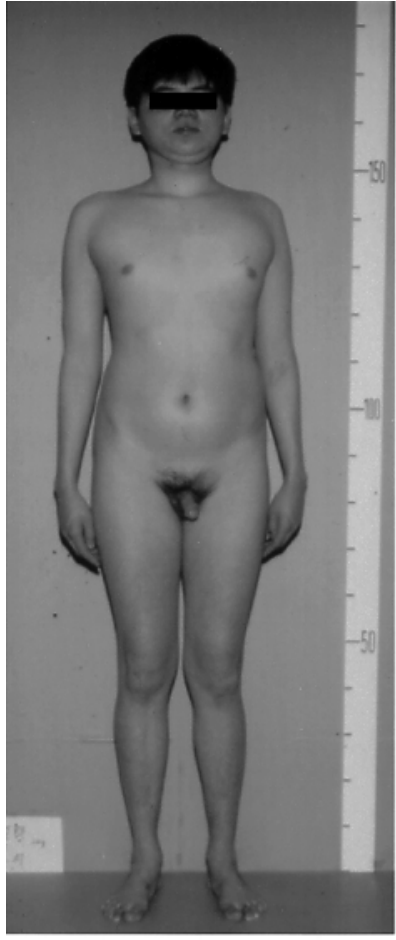

Patient 1
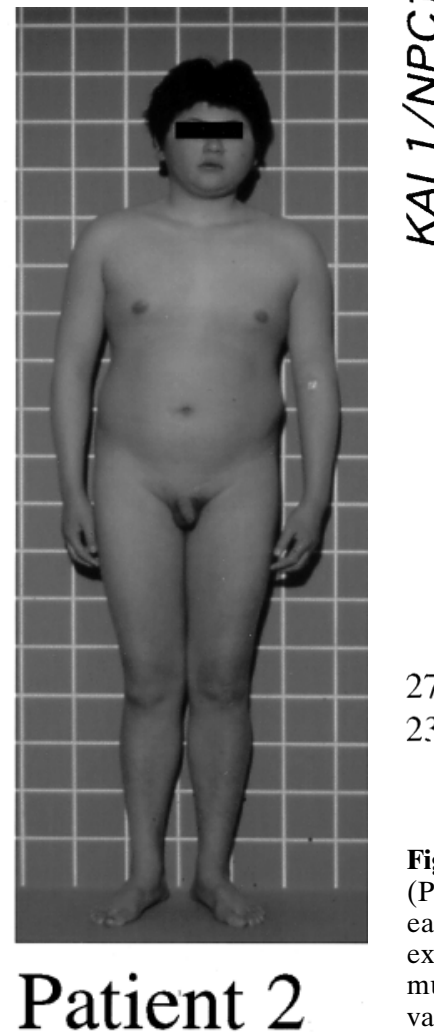

Fig. 1. Eunuchoidism of external genitalia (patients 1 and 2) and obesity (patient 2) confirm the carrier status of their mother, we quantified the gene dosage of $K A L 1$ exon 7 by comparative multiplex (CM)-PCR. This analysis of control male and female DNAs showed that the obtained gene dosage index (KAL1/NPC1 ratio) reflected the expected gene dosage ( 0.5 for males and 1.0 for females) within a cycle number of up to 23 (Fig. 2b). Because of deviation of the index from the actual gene dose with cycle numbers more than 23 , the cycle was set to 23 in the following experiments. CM-PCR analyses of the mother's DNA under this condition gave a KAL1/NPC1 ratio of 0.45 (mean; $n=5$; maximum ratio, 0.49 ; minimum ratio, 0.40 ), clearly indicating that she had only one allele of KAL1 exon 7. As expected, the ratio of the probands' DNAs was zero (Fig. 2c).

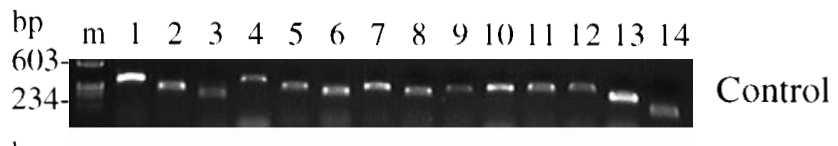

$\begin{array}{lllllllllllllllllll}\text { bp } & \mathrm{m} & 1 & 2 & 3 & 4 & 5 & 6 & 7 & 8 & 9 & 10 & 1 & 1 & 12 & 13 & 14\end{array}$

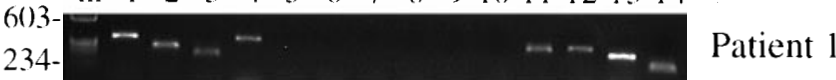

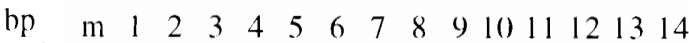

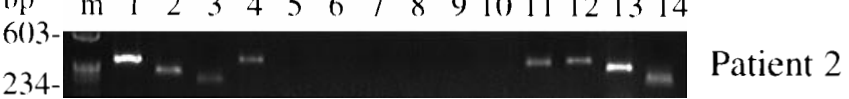

a

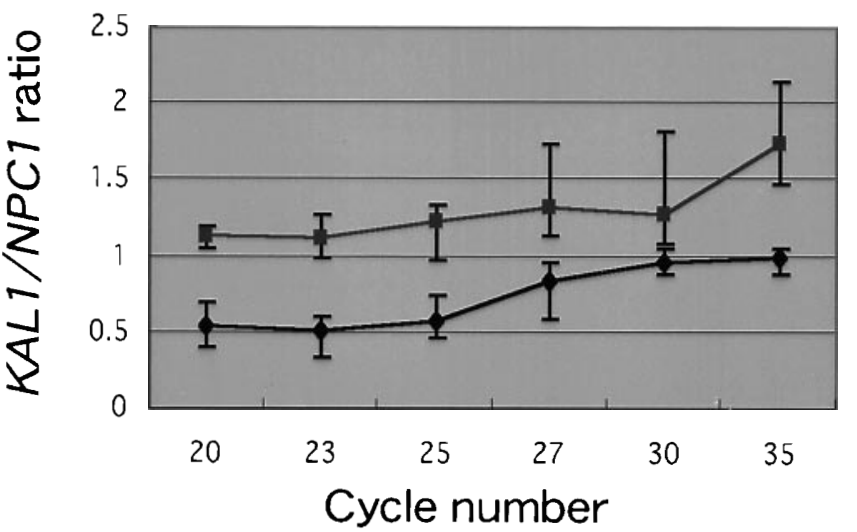

b

271-bp

234-bp

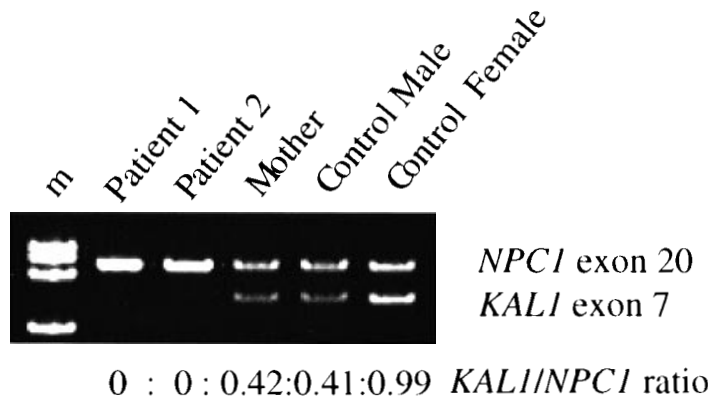

Fig. 2a-c. Molecular diagnosis for $K A L 1$. a Polymerase chain reaction (PCR) products of $K A L 1$ exons for each individual. The number of each exon is indicated above each lane. Underlines indicate the deleted exons. $m$, ФX174/Hae III digest. b $K A L 1 / N P C 1$ ratio (means \pm maximum and minimum) by use of comparative multiplex (CM)-PCR at various cycle numbers. Templates were genomic DNAs from ten male subjects (diamonds) and 11 female subjects (squares). c Representative results of five independent determinations by CM-PCR. Values for the $K A L 1 / N P C 1$ ratio are given below each lane. $m, \Phi \mathrm{X} 174 /$ HaeIII digest 
Table 1. KAL1 mutations in KS patients

\begin{tabular}{|c|c|c|c|c|c|c|}
\hline Authors & Year & $\begin{array}{l}\text { Location of } \\
\text { mutation }\end{array}$ & Mutation type & $\begin{array}{l}\text { Nucleotide } \\
\text { change }\end{array}$ & $\begin{array}{l}\text { Predicted amino } \\
\text { acid change }\end{array}$ & Neurological findings \\
\hline 1 Bick et al. & 1992 & Exon 12-14 & Exonic deletion & & & None \\
\hline 2 Hardelin et al. & 1992 & Exon 5 & Nonsense mutation & nt $711 \mathrm{G}>\mathrm{A}$ & Y237X & Synkinesia, epilepsy \\
\hline 3 & & Exon 6 & Nucleotide deletion & nt $831 \mathrm{C}$ del & Frameshift & Pes cavus deformity \\
\hline 4 & & Exon 6 & Nonsense mutation & nt $769 \mathrm{C}>\mathrm{T}$ & $\mathrm{R} 257 \mathrm{X}$ & $\begin{array}{l}\text { Synkinesia, pes cavus } \\
\text { deformity }\end{array}$ \\
\hline 5 & & Exon 6 & Nonsense mutation & nt $774 \mathrm{G}>\mathrm{A}$ & Y258X & Synkinesia \\
\hline 6 Meindl et al. & 1993 & All exons & Contiguous gene syndrome & & & Mental disturbance \\
\hline 7 Hardelin et al. & $1993 \mathrm{a}$ & All exons & Exonic deletion & & & Deafness \\
\hline 8 & & All exons & Exonic deletion & & & Synkinesia \\
\hline 9 Hardelin et al. & $1993 b$ & Exon 6 & Missense mutation & nt $801 \mathrm{~T}>\mathrm{A}$ & N267K & Not mentioned \\
\hline 10 & & Exon 7 & Nucleotide insertion & nt $1016 \mathrm{~A}$ ins & Frameshift & Not mentioned \\
\hline 11 & & Exon 9 & Nonsense mutation & nt $1261 \mathrm{C}>\mathrm{T}$ & Q421X & Not mentioned \\
\hline 12 & & Exon 9 & Nonsense mutation & nt $1267 \mathrm{C}>\mathrm{T}$ & $\mathrm{R} 423 \mathrm{X}$ & Synkinesia \\
\hline 13 & & Intron 12 & Nucleotide change & IVS $12-1 \mathrm{G}>\mathrm{A}$ & Splicing error & Not mentioned \\
\hline 14 Bouloux et al. & 1993 & & Contiguous gene syndrome & & & Mental disturbance \\
\hline 15 Klink et al. & 1994 & $?$ & Contiguous gene syndrome & & & Mental disturbance \\
\hline 16 Martul et al. & 1995 & All exons & Complete deletion & & & None \\
\hline 17 Parenti et al. & 1995 & Exon 2-14 & Exonic deletion & & Not expressed & Not mentioned \\
\hline 18 Quinton et al. & 1996 & All exons & Contiguous gene syndrome & & & Not mentioned \\
\hline 19 & & All exons & Exonic deletion & & & Not mentioned \\
\hline 20 & & Exon 1 & Exonic deletion & & Not expressed & Not mentioned \\
\hline 21 & & Exon 11 & Exonic deletion & & Frameshift & Not mentioned \\
\hline 22 & & Exon 12 & Nucleotide deletion & nt $1697 \mathrm{C}$ del & Frameshift & Deafness \\
\hline 23 Georgopoulos et al. & 1997 & Exon 10 & Nucleotide deletion & 14-bp del & Frameshift & Not mentioned \\
\hline 24 & & Exon 7 & Nonsense mutation & nt $984 \mathrm{C}>\mathrm{G}$ & Y328X & Not mentioned \\
\hline 25 & & Exon 8 & Nucleotide deletion & 9-bp del & Splicing error & Not mentioned \\
\hline 26 & & Exon 11 & Missense mutation & nt $1551 \mathrm{C}>\mathrm{G}$ & F517L & Not mentioned \\
\hline $27 \mathrm{Gu}$ et al. & 1998 & Exon 1 & Nucleotide insertion & nt 91 11-bp ins & Frameshift & Synkinesia \\
\hline 28 O’Neill et al. & 1998 & Intron 5 & Nucleotide change & IVS $5-1 \mathrm{G}>\mathrm{A}$ & Splicing error & Mental disturbance \\
\hline 29 Weissörtel et al. & 1998 & All exons & Contiguous gene syndrome & & & Mental disturbance \\
\hline 30 Maya-Núñez et al. & $1998 \mathrm{a}$ & Exon 1-3 & Contiguous gene syndrome & & & Not mentioned \\
\hline 31 Maya-Núñez et al. & $1998 b$ & Exon $3-5$ & Exonic deletion & & In frame & Synkinesia \\
\hline 32 & & Exon 11 & Missense mutation & nt $514 \mathrm{G}>\mathrm{A}$ & E514K & None \\
\hline 33 Maya-Núñez et al. & 1999 & None & Contiguous gene syndrome & & & Not mentioned \\
\hline 34 Izumi et al. & 1999 & Exon 1 & Nonsense mutation & nt $196 \mathrm{C}>\mathrm{T}$ & Q66X & None \\
\hline 35 Ours & 2000 & Exon 5-10 & Exonic deletion & & Frameshift & None \\
\hline
\end{tabular}

KS, Kallmann syndrome; nt, nucleotide; del, deletion; ins, insertion

More than 34 different mutations of $K A L 1$ have been reported to date (Table 1) (Bick et al. 1992; Hardelin et al. 1992; Meindl et al. 1993; Hardelin et al. 1993a,b; Bouloux et al. 1993; Klink et al. 1994; Martul et al. 1995; Parenti et al. 1995; Quinton et al. 1996; Georgopoulos et al. 1997; Gu et al. 1998; O'Neill et al. 1998; Weissörtel et al. 1998; MayaNúñez et al. 1998a,b and 1999; Izumi et al. 1999). Both of the patients described here had hypogonadism and hyposmia (the two hallmarks of KS), but they had no other neurological symptoms. Although a mental or intellectual disturbance was described in the original report of KS (Kallmann et al. 1944), recent analyses of the genotypephenotype relationship of this syndrome have shown that KS patients with mental disturbance had large deletions on Xp22.3 that extended beyond KAL1 (Table 1). In contrast, almost all of the patients with mutations restricted to the $K A L 1$ locus appeared to be free of mental disturbance. Therefore, another gene located close to KAL1 was speculated to be responsible for the mental disturbance (Prager and Braunstein 1993).

Acknowledgments We thank Dr. Takao Sasaki and Dr. Yukio Matsumoto for their encouragement during this project.

\section{References}

Bick D, Franco B, Sherins RJ, Heye B, Pike L, Crawford J, Maddalena A, Incerti B, Pragliola A, Meitinger T, Ballabio A (1992) Brief report: intragenic deletion of the KALIG-1 gene in Kallmann's syndrome. N Engl J Med 326:1752-1755

Bouloux P-MG, Kirk J, Munroe P, Duke V, Meindl A, Hilson A, Grant D, Carter N, Betts D, Meitinger T, Besser GM (1993) Deletion analysis maps ocular albinism proximal to the steroid sulphatase locus. Clin Genet 43:169-173

Georgopoulos NA, Pralong FP, Seidman CE, Seidman JG, Crowley WF, Vallejo M (1997) Genetic heterogeneity evidenced by low incidence of $K A L-1$ gene mutations in sporadic cases of gonadotropinreleasing hormone deficiency. J Clin Endocrinol Metab 82:213-217

Gu W-X, Colquhoun-Kerr JS, Kopp P, Bode HH, Jameson JL (1998) A novel aminoterminal mutation in the $K A L-1$ gene in a large pedigree with X-linked Kallmann syndrome. Mol Genet Metab 65:59-61

Hardelin J-P, Levilliers J, del Castillo I, Cohen-Salmon M, Legouis R, Blanchard S, Compain S, Bouloux P, Kirk J, Moraine C, Chaussain J-L, Weissenbach J, Petit C (1992) X-chromosome-linked Kallmann syndrome: stop mutations validate the candidate gene. Proc Natl Acad Sci USA 89:8190-8194

Hardelin J-P, Levilliers J, Young J, Pholsena M, Legouis R, Kirk J, Bouloux P, Petit C, Schaison G (1993a) Xp22.3 deletions in isolated familial Kallmann's syndrome. J Clin Endocrinol Metab 76:827-831

Hardelin J-P, Levilliers J, Blanchard S, Carel J-C, Leutenegger M, Pinard-Bertelletto J-P, Bouloux P, Petit C (1993b) Heterogeneity in 
the mutations responsible for $\mathrm{X}$ chromosome-linked Kallmann syndrome. Hum Mol Genet 2:373-377

Izumi Y, Tatsumi K, Okamoto S, Hosokawa A, Ueno S, Fukui H, Amino N (1999) A novel mutation of the KAL1 gene in Kallmann syndrome. Endocrinol J 46:651-658

Kallmann FJ, Schoenfeld WA, Barrera SE (1944) The genetic aspects of primary eunuchoidism. Am J Ment Defic 48:203-236

Klink A, Meindl A, Hellebrand H, Rappold GA (1994) A patient with an interstitial deletion in Xp22.3 locates the gene for X-linked recessive chondrodysplasia punctata to within a one megabase interval. Hum Genet 93:463-466

Martul P, Pineda J, Levilliers J, Vazquez JA, Rodriguez-Soriano J, Loridan L, Diaz-Perez JL (1995) Hypogonadotrophic hypogonadism with hyposmia, X-linked ichthyosis, and renal malformation syndrome. Clin Endocrinol 42:121-128

Maya-Núñez G, Cuevas-Covarrubias S, Zenteno JC, Ulloa-Aguirre A, Kofman-Alfaro S, Mendez JP (1998a) Contiguous gene syndrome due to deletion of the first three exons of the Kallmann gene and complete deletion of the steroid sulphatase gene. Clin Endocrinol 48:713-718

Maya-Núñez G, Zenteno JC, Ulloa-Aguirre A, Kofman-Alfaro S, Mendez JP (1998b) A recurrent missense mutation in the $K A L$ gene in patients with X-linked Kallmann's syndrome. J Clin Endocrinol Metab 83:1650-1653

Maya-Núñez G, Torres L, Ulloa-Aguirre A, Zenteno JC, CuevasCovarrubias S, Saavedra-Ontiveros D, Kofman-Alfaro S, Mendez JP
(1999) An atypical contiguous gene syndrome: molecular studies in a family with X-linked Kallmann's syndrome and X-linked ichthyosis. Clin Endocrinol 50:157-162

Meindl A, Hosenfeld D, Bruckl W, Schuffenhauer S, Jenderny J, Bacskulin A, Oppermann H-C, Swensson O, Bouloux P, Meitinger T (1993) Analysis of a terminal Xp22.3 deletion in a patient with six monogenic disorders: implications for the mapping of X-linked ocular albinism. J Med Genet 30:838-842

O’Neill MJ, Tridjaja B, Smith MJ, Bell KM, Warne GL, Sinclair AH (1998) Familial Kallmann syndrome: a novel splice acceptor mutation in the $K A L$ gene. Hum Mutat 11:340-342

Parenti G, Rizzolo MG, Ghezzi M, Di Maio S, Sperandeo MP, Incerti B, Franco B, Ballabio A, Andria G (1995) Variable penetrance of hypogonadism in a sibship with Kallmann syndrome due to a deletion of the $K A L$ gene. Am J Med Genet 57:476-478

Prager D, Braunstein GD (1993) X-chromosome-linked Kallmann's syndrome: pathology at the molecular level. J Clin Endocrinol Metab 76; 824-826

Quinton R, Duke VM, de Zoysa PA, Platts AD, Valentine A, Kendall B, Pickman S, Kirk JMW, Besser GM, Jacobs HS, Bouloux PMG (1996) The neuroradiology of Kallmann's syndrome: a genotypic and phenotypic analysis. J Clin Endocrinol Metab 81:3010-3017

Weissörtel R, Strom TM, Dorr HG, Rauch A, Meitinger T (1998) Analysis of an interstitial deletion in a patient with Kallmann syndrome, X-linked ichthyosis and mental retardation. Clin Genet $54: 45-51$ 